\title{
Antidiarrheal effect of extract from the bark of Combretum leprosum in mice
}

\author{
PAULO M.S. CAVALCANTI ${ }^{1}$, MARIA DO CARMO C. MARTINS ${ }^{2}$, PAULO H.M. NUNES ${ }^{2}$, \\ FRANCISCO C. ALVES FILHO ${ }^{2}$, JANYERSON D.P. SILVA ${ }^{2}$ and SUZANA M.G. CAVALCANTI ${ }^{3}$
}

\author{
${ }^{1}$ Departamento de Bioquímica e Farmacologia (setor SG8), Centro de Ciências da Saúde, Universidade \\ Federal do Piauí, Avenida Universitária, s/n, Ininga, 64049-550 Teresina, PI, Brazil \\ ${ }^{2}$ Departamento de Biofísica e Fisiologia (setor SG8), Centro de Ciências da Saúde, Universidade \\ Federal do Piauí, Avenida Universitária, s/n, Ininga, 64049-550 Teresina, PI, Brazil \\ ${ }^{3}$ Coordenação de Fisioterapia, Centro de Ciências da Saúde, Universidade Estadual do \\ Piauí, Rua Olavo Bilac, 2335, Centro (Sul), 64001-280 Teresina, PI, Brazil
}

Manuscript received on November 20, 2017; accepted for publication on May 7, 2018

\begin{abstract}
How to cite: CAVALCANTI PMS, MARTINS MCC, NUNES PHM, ALVES FILHO FC, SILVA JDP AND CAVALCANTI SMG. 2019. Antidiarrheal effect of extract from the bark of Combretum leprosum in mice. An Acad Bras Cienc 91: e20170932. DOI 10.1590/0001-3765201820170932.
\end{abstract}

\begin{abstract}
This study investigated the effects of the ethanolic extract from the bark of Combretum leprosum (ECL) on intestinal transit and castor-oil induced diarrhea in mice. The oral administration of ECL (750 and $1000 \mathrm{mg} / \mathrm{kg}$ ) slowed intestinal transit (ID50 of $455 \mathrm{mg} / \mathrm{kg}$ ). The ECL (250-1000 mg/kg) reduced castor-oil induced diarrhea, in a time- and dose-dependent manner $(\mathrm{p}<0.05)$. To determine if antidiarrheal effect of ECL involves $\alpha 2$-adrenergic or opioid receptor activation, the mice were pretreated with antagonists of these receptors, yohimbine or naloxone respectively. None of these drugs inhibited the antidiarrheal effect of ECL. To test if antidiarrheal effect of ECL is due to an antisecretory action, we realized the enteropooling assay on rats. The ECL increased bowel content and did not inhibit intestinal fluid secretion increase induced by misoprostol $(100 \mu \mathrm{g} / \mathrm{kg}$, s.c.). To determine if antimotility effect of ECL is due to a reduction on gastric motility, we realized the organ bath assay in the rat fundus stomach. Isotonic recordings show that the carbachol $/ \mathrm{KCl}$ - induced contraction was not reversed by the addition of ECL. In conclusion, our results suggest that ECL contains antidiarrheal compounds and these compounds could induce a reduction of intestinal tract motility.
\end{abstract}

Key words: Combretum leprosum, antidiarrheal effect, medicinal plants, polyphenols, intestinal transit, enteropooling.

\section{INTRODUCTION}

In children under 5 years of age, the diarrheal disease caused over 700.000 episodes of deaths in 2011, despite efforts made all over the world to reduce this number (Walker et al. 2013). In developing countries, diarrhea is the second leading

Correspondence to: Suzana Maria Galvão Cavalcanti

E-mail:smpgalvao@gmail.com

ORCid: http://orcid.org/0000-0002-1023-4420 cause of morbidity and mortality in children under 5 years of age (Liu et al. 2012) and in highly developed countries, it is the most common disease among travelers, affecting 20 to $50 \%$ of people in transit (Steffen et al. 2015). Diarrhea is defined as a gastrointestinal disorder marked by abnormal intestinal motility or an increased fluidity of the stool and/or presence of blood and mucus, due to an imbalance between the absorptive and secretory 
forces of the gastrointestinal tract (Field 2003, Petri Jr et al. 2008, Wood 2010). People with diarrhea may also present nausea, vomit, abdominal cramps and, as a result of these symptoms, be compelled to change their routine, which may force the affected individuals into bed rest until the hydroelectrolytic balance is restored through the reposition of the water and electrolytes lost.

Combretum leprosum, commonly known as "mofumbo", is a plant from the Combretaceae family, which is widely distributed in the Northeast region of Brazil. Infusions, decoctions and syrups prepared from the leaves, bark and roots of this plant are popularly used all over the Northeast of Brazil as a natural expectorant, as treatment for hemorrhages and the flu (Agra et al. 2008, Matos 1998).

Flower, leaf and root phytochemical analyses from $C$. leprosum have led to the isolation and identification of pentacyclic triterpenoids and the flavonoids 3-0-methylquercetin and quercetrin (Facundo et al. 1993). The active constituents found in the flowers, leaves and bark of the C. leprosum plant are responsible for its varied pharmacological effects. An example is the antinociceptive activity observed in mice treated with the ethanolic extract obtained from the flowers from C. leprosum, and subjected to chemical and thermal models of nociception (Pietrovski et al. 2006). C. leprosum was also able to reverse skin inflammatory and hyperproliferative processes, such as those provoked by 12-O-tetradecanoylphorbol-13acetate (TPA) and ear edema caused by croton oil, in classic models of inflammation (Horinouchi et al. 2013). The compounds triterpene $3 \beta$, $6 \beta$, 16 $\beta$-trihydroxylup-20(29)-ene (TTHL), isolated from the flowers of C. leprosum, as well as (-)-epicatechin, originated from the bark promoted antinociceptive activity (Pietrovski et al. 2006, Lopes et al. 2010). Furthermore, the oral administration of the ethanolic extract obtained from the flowers of $C$. leprosum diminished motor and molecular changes induced by the toxin 1-methyl-4-phenyl-1,2,3,6-tetrahydropyridine (MPTP) and partially reversed dopamine deficiency (Moraes et al. 2016), demonstrating the extract's therapeutic potential for the prevention and treatment of Parkinson's disease symptoms.

We have recently shown that the hydroethanolic extract from the bark of C. leprosum (ECL) exerts an extremely potent $\left(\mathrm{IC}_{50}=200 \mathrm{ng} / \mathrm{mL}\right.$ ) endothelium-mediated relaxation of precontracted arterial rings in different species of animals such as mice, rats, guinea pigs, rabbits and pigs (Alves Filho et al. 2015). Regarding the pharmacological activity of $C$. leprosum in the gastrointestinal tract, our previous work demonstrated that oral treatment with $C$. leprosum completely inhibited gastric ulcers induced by ethanol and partially reduced lesions induced by indomethacin, besides efficiently increasing the $\mathrm{pH}$ and reducing gastric acid secretion in rats subjected to a pyloric ligature model (Nunes et al. 2009). The applicable literature did not reveal any studies on the antidiarrheal activity of this species, even though this effect has been observed in other genera of the Combretaceae family (Aniagu et al. 2005, Cock 2015). Thus, the present work aims to investigate the antidiarrheal activity of the hydroethanolic extract from the bark of $C$. leprosum and the possible mechanisms involved in its pharmacological effects.

\section{MATERIALS AND METHODS}

\section{DRUGS USED IN THE EXPERIMENTS}

Atropine, carbachol, activated vegetable charcoal, clonidine, scopolamine, yohimbine, misoprostol, morphine, naloxone, castor oil, sodium thiopental and verapamil were obtained from Sigma-Aldrich Inc. (USA). The drugs were diluted in either saline or distilled water. 


\section{PLANT MATERIAL}

The stem bark from Combretum leprosum were collected on July 15th, 2013 in the Center of Agricultural Sciences of the Federal University of the state of Piauí (CCA/UFPI), located in the capital Teresina. Voucher specimens of the plant (number 10.557) were deposited on the Graziela Barroso herbarium at the Center of Natural Sciences of the aforementioned institution.

\section{EXTRACT PREPARATION}

The stem barks were dried in greenhouses at $40 \pm$ $1{ }^{\circ} \mathrm{C}$ and posteriorly crushed in an electric knife mill. Thereafter, the powder obtained underwent a process of five subsequent extractions and maceration with a $70 \%$ ethanol solution, in room temperature, every 3 to 4 days. The resulting extract was then concentrated using a rotary evaporator at $40{ }^{\circ} \mathrm{C}$, followed by dilution in demineralized water $(50 \mathrm{~mL}$ of the extract in $410 \mathrm{~mL}$ of water), homogenization in a magnetic stirrer along with the drying-adjuvant colloidal silicon dioxide (aerosil) and drying using the spray drying technique (Oliveira and Petrovick 2010). Finally, the dried residue was allocated in amber glass bottles and kept in room temperature.

\section{ANIMAL MODEL}

Swiss mice weighing 25 to $35 \mathrm{~g}$ and Wistar female rats from Central Vivarium/UFPI were used in the experiments after an adaptation phase to the research laboratory's conditions before being subjected to the experiment at the Biophysics and Physiology Laboratory at UFPI. The animals were fed with the standard commercial brand of food for rodents (Purina Chow) and had access to water ad libitum. They were kept under standard conditions with a $12 \mathrm{~h}$ light/dark cycle, 44 to $56 \%$ humidity and a temperature of $24 \pm 2{ }^{\circ} \mathrm{C}$. The animals were randomly divided into control and treatment groups of 10 animals per group. Experimental protocols were approved by the Ethics Committee for Animal Experimentation of the Federal University of Piauí (protocol number 065/15 for mice and protocol number $008 / 12$ for rats), in accordance with the ethical principles as set forth by the National Council of Animal Experimentation Control CONCEA.

\section{Small intestinal transit in mice}

In order to evaluate the effect of the stem bark extract from $C$. leprosum on intestinal motility, a model of intestinal transit using activated charcoal was applied, through which the speed of bowel transit was determined by the displacement of this marker, a fixed period of time after oral administration. The animals were adapted for a period of at least 4 days in metabolic cages as to prevent coprophagia, and kept in the standard conditions described in item "Animal Model". Food, but not water, was withdrawn 12 hours before the experiments. Six groups of ten mice each were treated orally either with distilled water or the hydroethanolic extract of Combretum leprosum (ECL 250, 500, 750 and $1000 \mathrm{mg} / \mathrm{kg}$ ) or morphine $(10 \mathrm{mg} / \mathrm{kg})$. Thirty minutes after treatment, the animals were given an aqueous suspension of activated charcoal $2.5 \%$ orally (charcoal meal) and after another 30 minutes, they were euthanized with a lethal dose of sodium thiopental $(100 \mathrm{mg} / \mathrm{kg}$, i.p. $=$ intraperitoneal). Then, the pylorus and ileocecal valve were surgically ligated and the small intestine was removed and outstretched on the surface of a petri dish. Intestinal transit was evaluated through the determination of the total distance traversed by the activated charcoal marker until the last portion of the bowel, which contained at least one continuous centimeter of charcoal, and expressed as a percentage in relation to the total length of the small intestine (Gurgel et al. 2001).

\section{Castor oil-induced diarrhea in mice}

The method used to evaluate the antidiarrheal effect of the extract of stem bark from C. leprosum was the same used by Awouters et al. (1978) with 
slight modifications. The animals were given at least 4 days to adapt to the conditions of the environment, housed in metabolic cages as to prevent coprophagia, and kept under the standard conditions described in item "Animal Model". Food, but not water, was withdrawn 12 hours before the experiments and the animals were divided into seven groups of ten animals each. The animals from the first and second groups received the vehicle (distilled water $10 \mathrm{~mL} / \mathrm{kg}$, p.o. = per oral), while the animals from the third to the sixth group received the hydroethanolic extract from C. leprosum (ECL) at the doses of 250, 500, 750 and $1000 \mathrm{mg} / \mathrm{kg}$ (p.o./ gavage) respectively. The seventh group was injected subcutaneously with morphine at the dose of $10 \mathrm{mg} / \mathrm{kg}$. After 60 minutes of each treatment, the animals from the first group received distilled water orally and all the other groups were given castor oil ( $0.2 \mathrm{ml} /$ animal). Thereafter, the animals were individually observed for 4 hours during which the number of solid and liquid evacuations were quantified, initially every $30,60,120,180$ and 240 minutes after administration, with the purpose of assessing the evolution and intensity of castoroil induced diarrhea.

\section{Castor oil-induced diarrhea in mice pretreated with naloxone}

Aiming to investigate the involvement of opioid receptors on the antidiarrheal effect of ECL, 5 groups of animals (10 animals per group) were pretreated with naloxone $(2 \mathrm{mg} / \mathrm{kg}$, s.c. $)$, followed by treatment with ECL $(500,750$ or $1000 \mathrm{mg} / \mathrm{kg}$, p.o.), distilled water (10 mg/kg, p.o.), or morphine $(10 \mathrm{mg} / \mathrm{kg}$, s.c = subcutaneous $)$, after which diarrhea was induced with castor oil, as described above (item Castor oil-induced diarrhea in mice).

\section{Castor oil-induced diarrhea in mice pretreated with yohimbine}

The participation of $\alpha 2$-adrenergic receptors in the antidiarrheal effect of ECL was investigated through the pretreatment of 3 groups of animals ( 7 animals per group) with yohimbine (5 mg/kg, s.c.) and then, distilled water $(10 \mathrm{~mL} / \mathrm{kg}$, p.o.), ECL (1000 mg/ $\mathrm{kg}$, p.o.) or clonidine $(0.1 \mathrm{mg} / \mathrm{kg}$, p.o.), after which diarrhea was induced with castor oil, as described in item Castor oil-induced diarrhea in mice.

\section{Effects of ECL on fluid intestinal secretion (enteropooling) induced by misoprostol on the intestines of rats}

The effect of ECL on intestinal secretion (enteropooling) induced by misoprostol was investigated based on the methodology developed by Robert et al. (1976) and Beubler and Lembeck (1980). Six groups ( $n=6-8$ animals / group) of female Wistar rats were deprived of solid food for 18 hours and then divided into two subgroups of three groups each. The first three groups were treated with distilled water ( $5 \mathrm{~mL} / \mathrm{kg})$, ECL ( $750 \mathrm{mg} / \mathrm{kg}$ p.o.) or scopolamine $(20 \mathrm{mg} / \mathrm{kg}$ p.o.) and after one hour with misoprostol (MISO $100 \mu \mathrm{g} / \mathrm{kg}$ s.c., dissolved in 5\% ethanol). The other three groups were treated with water $(5 \mathrm{~mL} / \mathrm{kg})$, ECL $(750 \mathrm{mg} / \mathrm{kg})$ or scopolamine $(20 \mathrm{mg} / \mathrm{kg}$ ) and one hour later with 5\% ethanol (5 $\mathrm{mL} / \mathrm{kg}$ ). Half an hour later, all of the animals were euthanized and the small intestines were surgically removed after ligature of the pylori and of the ileocecal valves. The intestines were then weighed before and after removal of the intestinal content in order to determine intestinal secretion (mass in grams). The data were expressed as mean \pm standard deviation ( $\mathrm{M} \pm$ D.P.). The statistical analysis were carried out using ANOVA and Tukey's multiple comparisons test. Statistical significance was assumed at $\mathrm{p}<0.05$.

\section{FUNCTIONAL STUDIES}

The Wistar rats (180-220 g) were euthanized with a sodium thiopental overdose, followed by the extraction of the gastric fundus (Smaili et al. 1998). Strips of longitudinal smooth muscle, recorded under isotonic conditions, were then prepared and 
mounted into isolated $10 \mathrm{~mL}$ organ baths consisting of a Tyrode solution of $136.8 \mathrm{mM}$ of $\mathrm{NaCl}, 2.7 \mathrm{mM}$

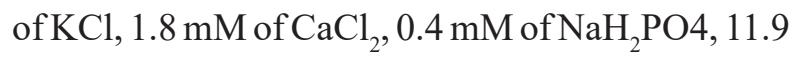
$\mathrm{mM}$ of $\mathrm{NaHCO}_{3}$ and $5.6 \mathrm{mM}$ of glucose $(\mathrm{pH} 7.4$ at $37{ }^{\circ} \mathrm{C}$ ), gassed with atmospherical air. A resting tension of $1 \mathrm{~g}$ was exerted and kept throughout the experiment. The tissues were allowed to stabilize for one hour during which the tissue was repeatedly washed with the Tyrode solution every 10 to 15 minutes, followed by a test of the viability of the preparation through the addition of $\mathrm{KCl}$ (40-80 $\mathrm{mM})$. After the equilibrium period, the preparation was once again washed for 30 minutes and either carbachol or $\mathrm{KCl}$ was added. When the plateau of the contractile responses induced by carbachol or $\mathrm{KCl}$ was reached, ECL (100-300 $\mu \mathrm{g} / \mathrm{mL})$, atropine (100-300 $\mathrm{nM})$ or verapamil $(1-10 \mu \mathrm{M})$ were added to the preparation.

\section{STATISTICAL ANALYSIS}

The results are presented as mean \pm standard deviation ( $\mathrm{M} \pm$ D.P.). The value for the $\mathrm{ID}_{50}$ (dose for semi-maximum inhibition response) was calculated using a linear regression test (GraphPadPrism ${ }^{\circledR}$ - GraphPad Software, Inc.). The groups were compared using the two-way analysis of variance (Two-way ANOVA), followed by the Duncan post hoc test. Statistical significance was assumed at $\mathrm{p}<0.05$.

\section{RESULTS}

\section{EFFECT OF BARK EXTRACT FROM THE STEM OF} Combretum leprosum IN MICE BOWEL TRANSIT

The investigation of the effect of bark extract from the stem of Combretum leprosum in the normal bowel transit of mice (Table I), revealed that the groups treated with ECL (750 and $1.000 \mathrm{mg} / \mathrm{kg}$, p.o.) presented a significantly shortened intestinal transit time $(\mathrm{p} \leq 0.05)$ when compared to the control group. The calculated $\mathrm{ID}_{50}$ was $455 \mathrm{mg} / \mathrm{kg}$. The subcutaneous administration of a single dose of morphine $(10 \mathrm{mg} / \mathrm{kg})$, used as a positive control, significantly inhibited normal intestinal transit in mice (Table I).

\section{EFFECT OF BARK EXTRACT FROM THE STEM} OF Combretum leprosum IN AN INTESTINAL

HYPERMOTILITY MODEL INDUCED BY CASTOR OIL

The extract's antidiarrheal effect on castor-oil induced diarrhea was evaluated through the quantification of liquid stool eliminated (Figure 1). We demonstrated that a dose of $0.2 \mathrm{~mL}$ of castoroil caused a significant increase in the number of diarrheal episodes, as promptly as 60 minutes after administration, which persisted for up to 120 minutes. In contrast, the oral administration of ECL $(250,500,750$ and $1000 \mathrm{mg} / \mathrm{kg}$ ) promoted a statistically significant reduction of castor-oil induced diarrhea in a dose- and time-dependent

TABLE I

Effect of the administration of a suspension of the hydroethanolic extract of stem bark of Combretum leprosum (ECL) $(250,500,750$ and $1000 \mathrm{mg} / \mathrm{kg}$, p.o.) or morphine $(10 \mathrm{mg} / \mathrm{kg}, \mathrm{s.c}$.) upon intestinal transit in mice. The values are expressed in mean percentages.

\begin{tabular}{cccc}
\hline Treatment & Dose $(\mathbf{m g} / \mathbf{k g})$ & Intestinal Transit $(\%)$ & Inhibition $(\%)$ \\
\hline ECL & 250 & $54.5 \pm 2.6^{*}$ & 3.5 \\
& 500 & $53.8 \pm 3.8^{*}$ & 4.8 \\
& 750 & $45.2 \pm 2.1^{*}$ & 20.0 \\
Morphine & 1000 & $17.2 \pm 5.5^{* *}$ & 69.6 \\
Distilled water & 10 & $14.2 \pm 4.0 * *$ & 74.9 \\
\hline
\end{tabular}

$* \mathrm{p}<0.05$ and $* * \mathrm{p}<0.01$. Statistically significant in relation to distilled water (Duncan's Test). \# $\mathrm{p}<0.05$. Statistically significant in relation to morphine (Duncan's Test). 
manner. Only 60 minutes after treatment, was the diarrhea induced by castor oil completely abolished in the groups of mice treated with ECL at 500, 750 and $1000 \mathrm{mg} / \mathrm{kg}$ (Figure 1b). However, this effect seems to be reversible, given that 180 minutes after administration, the number of liquid evacuations, although still significantly reduced, was no longer abolished (Figure 1d). Combretum leprosum extract at the dose of $500 \mathrm{mg} / \mathrm{kg}$, but not at $250 \mathrm{mg} / \mathrm{kg}$, significantly decreased castor oil induced diarrhea episodes after 60 minutes (Figure 1b).

INVOLVEMENT OF $\alpha_{2}$-ADRENERGIC RECEPTORS ACTIVATION IN THE ANTIDIARRHEAL EFFECT OF THE EXTRACT OF BARK FROM THE STEM OF Combretum leprosum IN A MODEL OF INTESTINAL HYPERMOTILITY INDUCED BY CASTOR OIL

In order to evaluate the involvement of the activation of $\alpha_{2}$-adrenergic receptors on the antidiarrheal effect of ECL, we quantified the total number of liquid evacuations over a period of 240 minutes. Therefore, as illustrated in Figure 2a, ECL at the doses of 500,750 and $1000 \mathrm{mg} / \mathrm{kg}$ significantly reduced castor-oil induced diarrhea for up to 240 minutes. Under the experimental conditions of the present study, the $\alpha_{2}$-adrenergic antagonist, yohimbine (YOM $5 \mathrm{mg} / \mathrm{kg}$, s.c.), only blocked the antidiarrheal effect of the $\alpha_{2}$ - adrenergic agonist clonidine (CLO $0.1 \mathrm{mg} / \mathrm{kg}$, p.o.) after 240 minutes of inducing diarrhea with castor oil (Figure 2b). Considering the same interval, the previous administration of yohimbine did not reduce the antidiarrheal effect promoted by ECL at the dose $1000 \mathrm{mg} / \mathrm{kg}$, differently than what was shown for clonidine (Figure $2 b$ ).

\section{INVOLVEMENT OF OPIOID RECEPTOR} ACTIVATION IN THE ANTIDIARRHEAL EFFECT OF THE EXTRACT OF BARK FROM THE STEM OF Combretum leprosum IN A MODEL OF INTESTINAL HYPERMOTILITY INDUCED BY CASTOR OIL

In order to evaluate the involvement of the activation of opioid receptors on the antidiarrheal effect of the ECL, morphine was used as a positive control (MOR
$10 \mathrm{mg} / \mathrm{kg}$, s.c.), administered before castor oil. In this experimental protocol, morphine abolished diarrhea completely 60 minutes after treatment with castor oil (Figure 3b), but not at the end of 120 minutes. Since not only the antidiarrheal effect of ECL at the dose of $500 \mathrm{mg} / \mathrm{kg}$, but also that of morphine tends to be reversed at 120 minutes (Figure 3c), we decided to investigate if ECL exerted its antidiarrheal effect through the activation of opioid receptors. When treated beforehand with naloxone (NLX $2 \mathrm{mg} / \mathrm{kg}$, s.c.), a powerful opioid antagonist, the inhibition of the antidiarrheal effect of ECL in mice was not observed for all tested doses, even though it completely antagonized morphine's effect (Figure $3 b)$. Furthermore, no additional or synergistic antidiarrheal effect was detected by concomitant treatment with ECL and morphine. Curiously, the group of mice treated only with naloxone presented significantly more diarrhea during the first 30 minutes after administration of castor oil (Figure 3a). Another intriguing realization was that both the administration of ECL at the doses of 500, 750 and $1000 \mathrm{mg} / \mathrm{kg}$ and morphine successfully inhibited the intensification of the diarrhea previously observed at 30 minutes after the administration of castor oil and potentialized by naloxone (Figure 3a).

EFFECT OF THE EXTRACT OF BARK FROM THE STEM OF Combretum leprosum IN INTESTINAL FLUID ACCUMULATION

Aiming to determine if the antidiarrheal effect of ECL was a result of an antisecretory activity of intestinal fluid, we conducted a misoprostolinduced secretory test. As shown on Figure 4, oral administration of one antidiarrheal dose of ECL $(750 \mathrm{mg} / \mathrm{kg}$, p.o.) failed to inhibit the increase in fluid induced by misoprostol (MISO $100 \mu \mathrm{g} / \mathrm{Kg}$, s.c.), whereas scopolamine (SCO $20 \mathrm{mg} / \mathrm{Kg}$, p.o.) successfully reduced the accumulation of fluid under the same circumstances, from $3.27 \pm 0.36$ $(\mathrm{n}=6)$ to $2.60 \pm 0.28(\mathrm{n}=6), \mathrm{p}<0.05$. Surprisingly, the sole administration of ECL significantly 

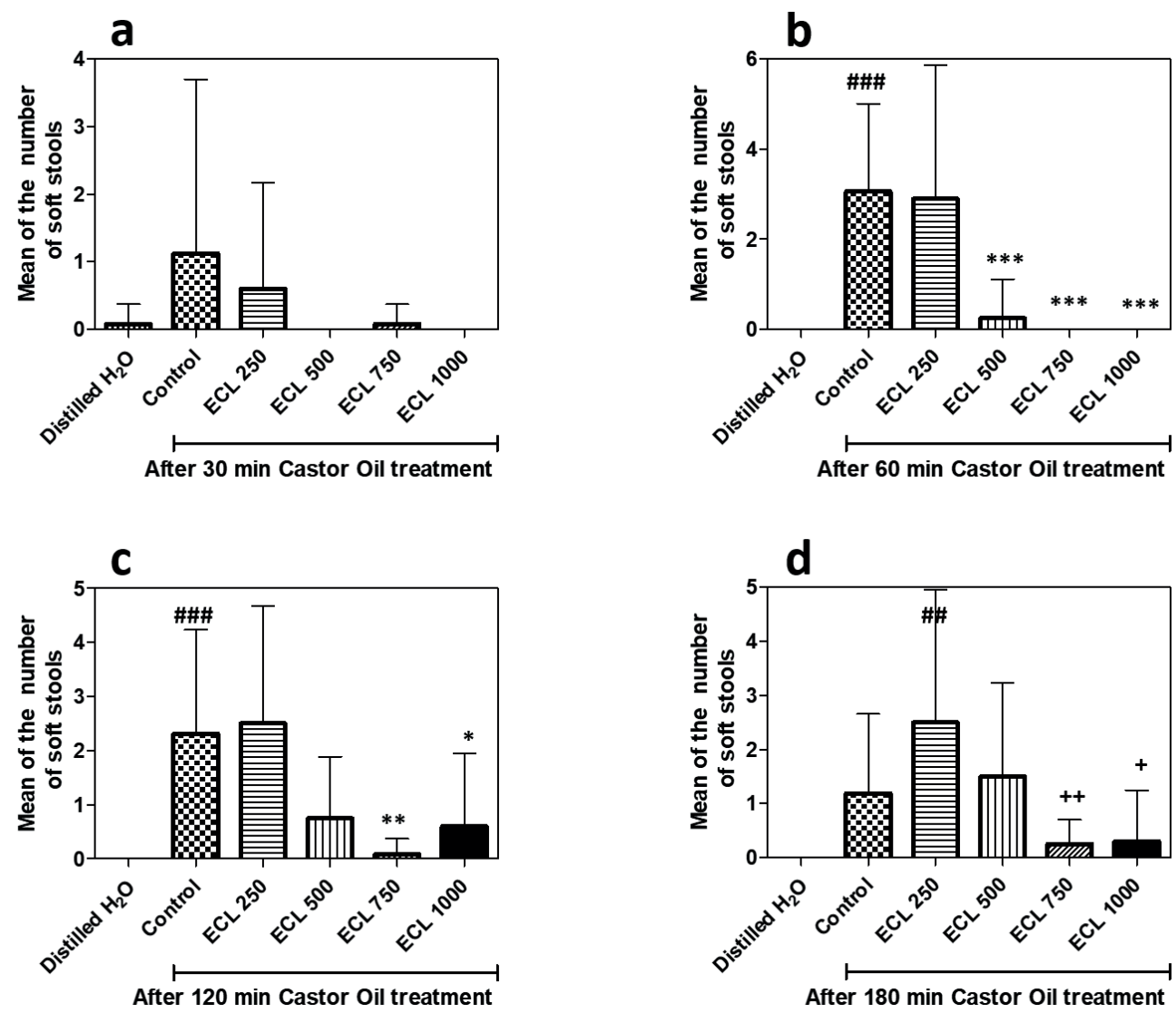

Figure 1 - Mean number of liquid stools (diarrhea) induced by castor oil $(\mathrm{CO})$ in mice groups $(\mathrm{n}=$ 7-16 animals per group) treated orally with acute doses of ECL $(250,500,750$ and $1000 \mathrm{mg} / \mathrm{Kg})$. The number of liquid stools was evaluated at 30, 60, 120 and 180 minutes after administration of CO (a-d panels). Distilled water was used as vehicle for ECL. The values are expressed as mean (bars) \pm standard deviation (lines). ${ }^{\# \#} \mathrm{p}<0.01,{ }^{\#} \mathrm{p}<0.05$. Statistically significant in relation to distilled water group (Duncan's Test). ${ }^{* * *} \mathrm{p}<0.01,{ }^{* *} \mathrm{p}<0.02$ and ${ }^{*} \mathrm{p}<0.05$. Statistically significant in relation to control group (Duncan's Test). ${ }^{++} \mathrm{p}<0.01,{ }^{+} \mathrm{p}<0.05$. Statistically significant in relation to ECL 250 group (Duncan's Test).

increased stool content from $1.00 \pm 0.20 \mathrm{~g}(\mathrm{n}=7)$ to $3.06 \pm 0.34 \mathrm{~g}(\mathrm{n}=6), \mathrm{p} \leq 0.001$. An isolated administration of scopolamine did not significantly alter intestinal content mass $(1.67 \pm 0.27 \mathrm{~g} ; \mathrm{n}=7)$.

\section{EFFECT OF THE EXTRACT OF BARK FROM THE STEM OF Combretum leprosum IN ISOLATED RAT GASTRIC FUNDUS PREPARATIONS}

Our study showed that the addition of ECL was not enough to reverse the sustained tonic contractions induced by carbachol $(100 \mathrm{nM})$ or high potassium (KCl $40 \mathrm{mM}$ ). Nevertheless, atropine (ATR 100 $\mathrm{nM}$ ) and verapamil (VER $10 \mu \mathrm{M}$ ), successfully reversed the contractile responses induced by carbachol (CCh $100 \mathrm{nM})$ and high potassium $(\mathrm{KCl}$ $40 \mathrm{mM}$ ), respectively (Figure 5).

\section{DISCUSSION}

The present study has demonstrated and characterized the effect of an aqueous suspension of the hydroalcoholic extract of bark from the plant Combretum lemprosum (ECL) on the inhibition of basal intestinal transit and castor oil induced diarrhea in mice. Other species from the Combretaceae family have already been reported to inhibit bowel transit, as well as diarrhea induced by castor oil, such as the aqueous extract from 

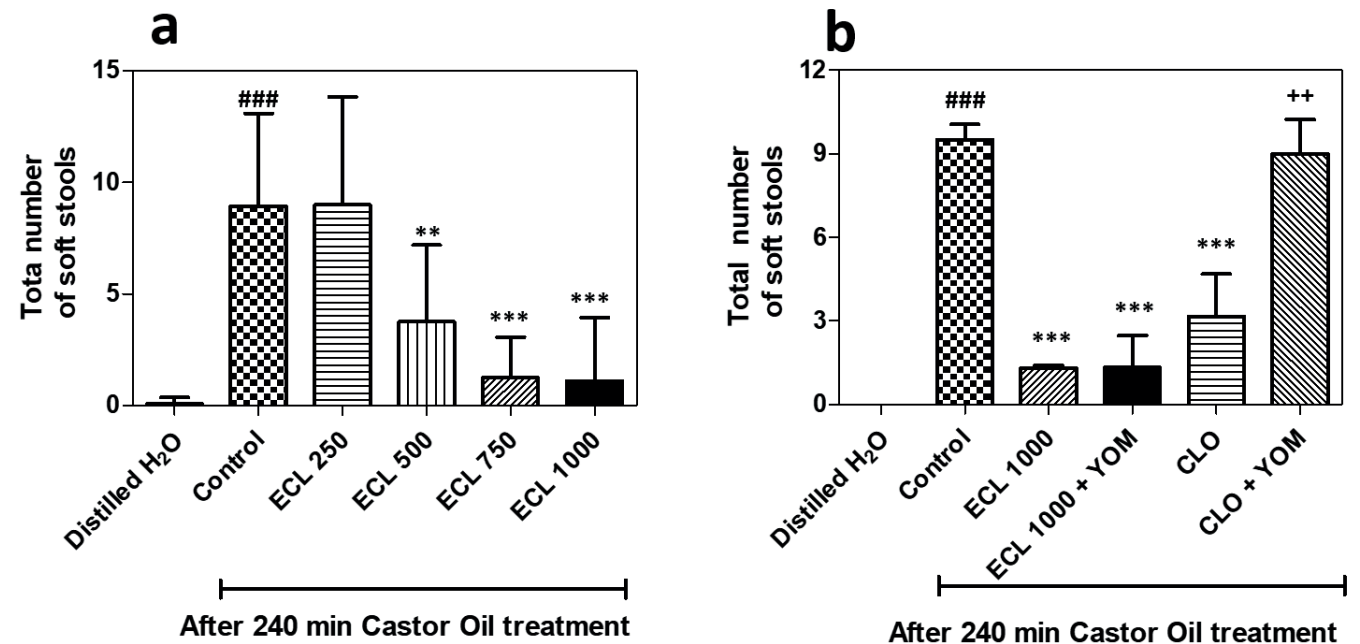

After 240 min Castor Oil treatment

Figure 2 - Total number of liquid evacuation episodes after $240 \mathrm{~min}$ of castor oil (CO) treatment in the mice groups ( $\mathrm{n}=7-16$ animals per group) previously treated orally with different acute doses of ECL at absence (a, ECL 250, 500, 750 and $1000 \mathrm{mg} / \mathrm{Kg}$ ) and presence of YOM (b, ECL $1000 \mathrm{mg} / \mathrm{Kg}$ ). Liquid stools episodes were counted during the whole period of 240 minutes after administration of CO. Distilled water was used as vehicle for ECL. The values are expressed as mean (bars) \pm standard deviation (lines). CLO = clonidine and $\mathrm{YOM}=$ yohimbine. $\# \# \# \mathrm{p}<0.001$. Statistically significant in relation to distilled water group (Duncan's Test). ${ }^{* * *} \mathrm{p}<0.001$ and ${ }^{* *} \mathrm{p}<0.01$. Statistically significant in relation to control group (Duncan's Test). $++p$ $<0.05$. Statistically significant in relation to CLO group (Duncan's Test).

the roots of the african plant Guiera senegalensis (Aniagu et al. 2005) and from fruit of the Chinese plant Terminalia chebula Retz (Sheng et al. 2016). However, distinctively from these extracts, which inhibit the fluid accumulation in the intestinal lumen induced by castor oil, as seen in enteropooling assays in rats, ECL did not alter misoprostol-induced fluid build-up. Thus, the antidiarrheal activity of ECL may result primarily from the modulation of intestinal motility instead of secretion.

One possibility that might explain the delay in intestinal transit time, as well as the antidiarrheal activity observed, is the hypothesis that active principles within ECL promote effects similar to those of atropine, hence, of a muscarinic receptor antagonist (Awouters et al. 1983). We observed that atropine reverted carbachol-induced contractions completely, whereas ECL failed to reverse these contractions in the rat gastric fundus strips. Therefore, it was discarded that ECL contains compounds similar to antimuscarinics. In fact, previous works have shown that ECL promotes potent and prolonged endothelial-mediated vasorelaxation of aortic arterial rings of several species of animals. This relaxation does not seem to happen through the activation of muscarinic receptors, given that atropine $(0.1 \mu \mathrm{M})$ failed to reverse the relaxation promoted by ECL, but did reverse that caused by $1 \mu \mathrm{M}$ of acetylcholine (Alves Filho et al. 2015). The presence of compounds with effects similar to those of voltage-operated channel blockers can also be excluded due to the fact that the contractions induced by $\mathrm{KCl}$ were annulled by the addition of verapamil, but not ECL.

Evidence shows that ATP-sensitive $\mathrm{K}^{+}$channel activators, such as pinacidil and cromakalim, promote a delay of intestinal transit time and inhibit castor oil induced diarrhea in mice (Poggioli et al. 1995). Additionally, it has been asserted that in the longitudinal strips of rat gastric fundus, the contractions induced by acetylcholine, $\mathrm{KCl}$, 

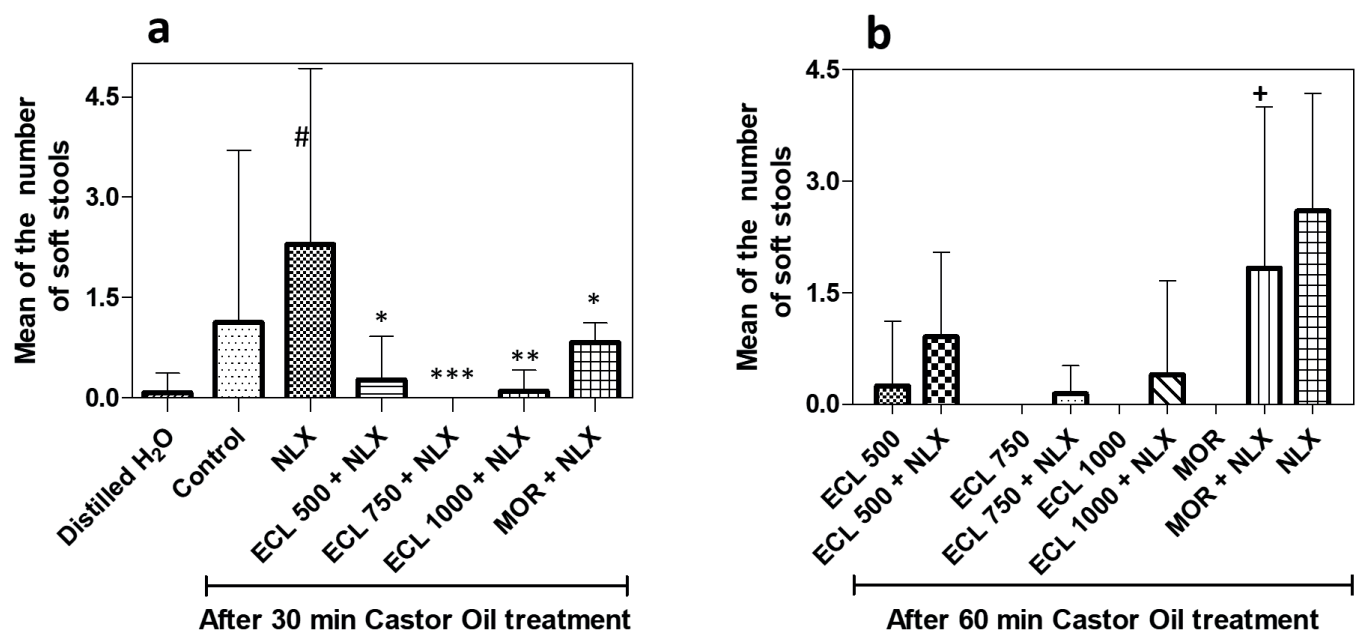

Figure 3 - Mean number of liquid stools (diarrhea) induced by castor oil (CO) in the mice groups (n=7-16 animals per group) treated orally with acute doses of ECL (500, 750 and $1000 \mathrm{mg} / \mathrm{Kg}$ ) or morphine (MOR $10 \mathrm{mg} / \mathrm{kg}$, s.c.) plus naloxone (NLX $2 \mathrm{mg} / \mathrm{Kg}$, s.c.). The numbers of the liquid stools were evaluated at 30 (a) and 60 (b) minutes after administration of CO. Distilled water was used as vehicle for ECL. The values are expressed as mean (bars) \pm standard deviation (lines). ${ }^{*} \mathrm{p}<0.02$. Statistically significant in relation to distilled water group (Duncan's Test). ${ }^{* * *} \mathrm{p}<0.01,{ }^{* *} \mathrm{p}<0.02$ and ${ }^{*} \mathrm{p}<0.05$. Statistically significant in relation to NLX group (Duncan's Test). ${ }^{+} \mathrm{p}<0.05$. Statistically significant in relation to MOR group (Duncan's Test).

serotonin and $\mathrm{PGF}_{2 \alpha}$ were inhibited by pinacidil and/or cromakalim (Buharalioğlu and Akar 2002, Lefebvre and Horacek 1992). Given that we did not observe any relaxant effects related to ECL in these preparations, it's unlikely that it acts as an ATP-sensitive $\mathrm{K}^{+}$channel activator.

Recently, we have documented that $60 \%$ of ECL is composed by polyphenols, which react similarly to quercetin and gallic acid (Alves Filho et al. 2015). Some compounds have already been purified and isolated from the ethanolic extracts obtained from the roots, stem bark, leaves and flowers of Combretum leprosum and the possibility that one of these might mediate the antidiarrheal effect of ECL will be further discussed here.

Flavonoids are polyphenolic compounds capable of promoting antimotility and antidiarrheal effects in mice (Di Carlo et al. 1993). The following flavonoids have been isolated from Combretum leprosum: quercetrin and 3-O-methylquercetin, from the roots and leaves, 5,7,3',4'-tetrahydroxy3-methoxyflavone, 5,3', 4' -trihydroxy-3,7-

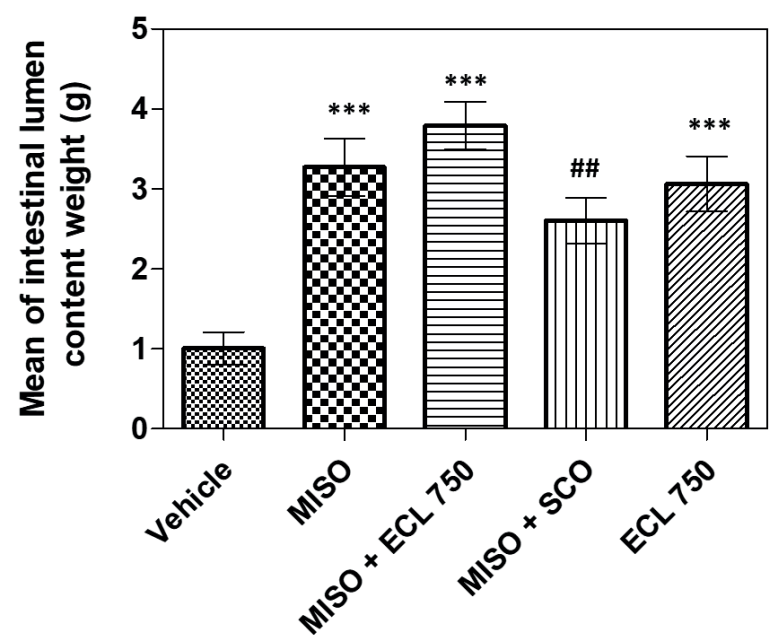

Figure 4 - Mean intestinal lumen content weight $(\mathrm{g})$ in the mice groups ( $n=6-7$ animals per group) treated acutely with misoprostol (MISO $100 \mu \mathrm{g} / \mathrm{Kg}$, s.c.), misoprostol plus ECL 750 (MISO $100 \mu \mathrm{g} / \mathrm{kg}$, s.c. + ECL $750 \mathrm{mg} / \mathrm{Kg}$, p.o.), misoprostol plus scopolamine (MISO $100 \mu \mathrm{g} / \mathrm{Kg}$ s.c. + SCO $20 \mathrm{mg} / \mathrm{Kg}$, p.o.), and ECL 750 (ECL $750 \mathrm{mg} / \mathrm{Kg}$, p.o.). Distilled water administered orally was used as the vehicle for both ECL and scopolamine. The values are expressed as mean (bars) \pm standard deviation of the mean (lines). ${ }^{* * *} \mathrm{p}<0.001$. Statistically significant in relation to vehicle (distilled water group) (Duncan's Test). ${ }^{\#} \mathrm{p}<0.05$. Statistically significant in relation to MISO group (Duncan's Test). 


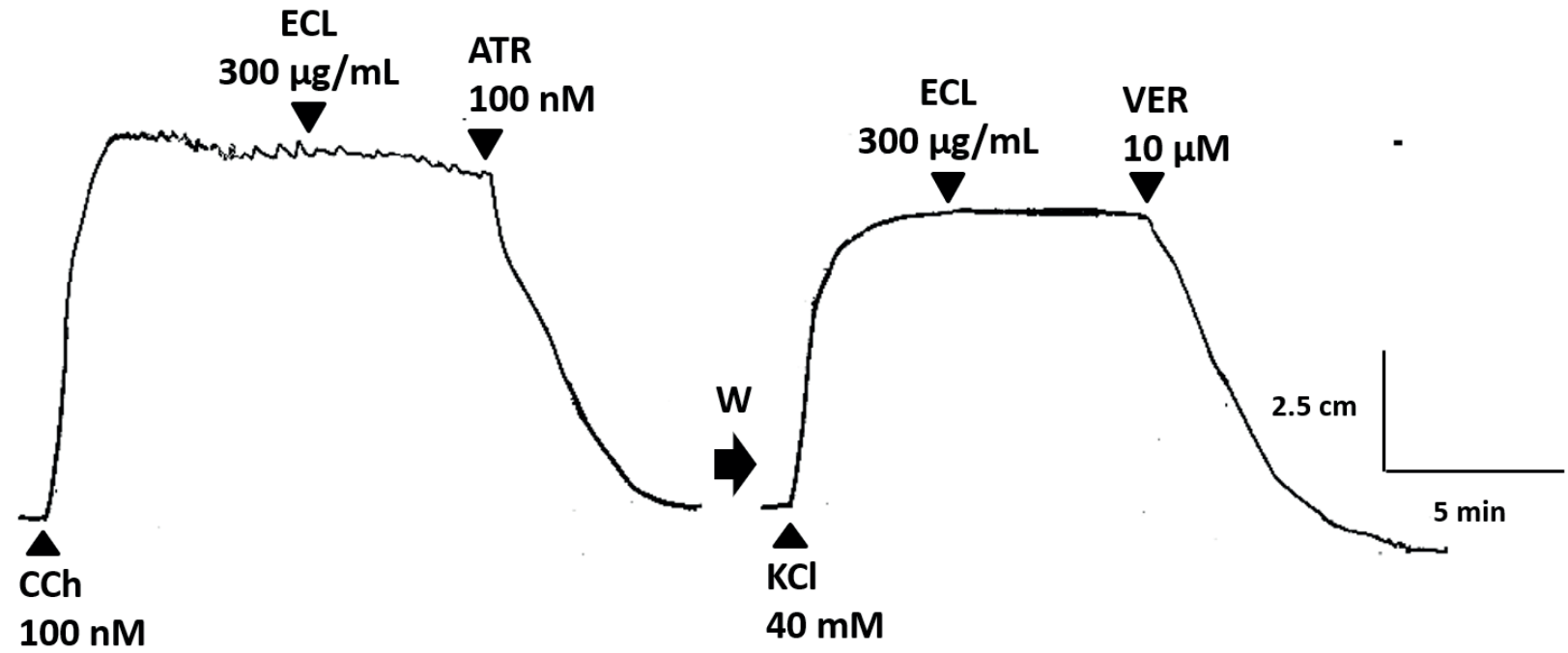

Figure 5 - Representative isotonic recordings of the 3 experiments realized in the longitudinal strips isolated from smooth muscle of the rat stomach fundus. After stabilization period for 1 hour and contractile viability tests with high potassium $(\mathrm{KCl}, 40 \mathrm{mM})$, the muscle was contracted by carbachol (CCh, $100 \mathrm{nM})$ and ECL $(300 \mu \mathrm{g} / \mathrm{mL})$ was added. Subsequently after 40-60 min of the washout (W), the preparation was contracted by high potassium $(\mathrm{KCl}, 40 \mathrm{mM})$ and ECL $(300 \mu \mathrm{g} / \mathrm{mL})$ again was added. ATR $=$ atropine and VER = verapamil.

dimethoxyflavone and 5,3'-dihydroxy-3,7,4'trimethoxyflavone, from the flowers and (-)-epicatechin from stem bark (Facundo et al. 1993). Therefore, it can be suggested that a class of flavonoid compounds could be responsible for the inhibitory effects of ECL on intestinal transit and therefore of its antidiarrheal effects. However, this possibility is contradicted by the fact that yohimbine antagonizes the antidiarrheal effects of some flavonoids (Di Carlo et al. 1993), but not of ECL as shown in our experiments. Therefore, these evidences suggest that the antidiarrheal effect of ECL does not involve the activation of $\alpha_{2}-$ adrenergic receptors.

Epicatechin has been isolated from the bark from Combretum leprosum and due to the fact that there is evidence that this compound bears the ability to inhibit bowel transit in mice, it's reasonable to suggest that the inhibitory effect of ECL results from the presence of epicatechin in the Combretum leprosum extract. On the other hand, the inhibitory effect of epicatechin on bowel transit is inhibited by yohimbine and naloxone
(Viswanathan et al. 1984), antagonists which, in our experiments, failed to inhibit the antidiarrheal effect of ECL, indicating that this effect does not involve direct activation of opioid receptors either.

Furthermore, flavonoids exhibit antisecretory activity in rats subjected to the enteropooling test (Di Carlo et al. 1993), whereas our results have shown that ECL causes elevation of the intestinal fluid content, which suggests it promotes a stimulatory rather than an inhibitory effect on intestinal fluid secretion. This stimulatory effect might be explained by the fact that the same extract is composed by a large number of oligomeric procyanidins (E. Šehmehmedović et al., unpublished data), a subclass of polyphenolic compounds widely present in vegetable sources. There have been reports that the procyanidins from black bean peel (in concentrations from 0.6 to $2.0 \mathrm{mg} / \mathrm{mL}$ ) inhibit sodium, alanine and glucose absorption and stimulate chloride secretion in rat ileum segments (Silverstein et al. 1996), which might result in a global increase of liquid and electrolyte content in the intestinal lumen. 
Interestingly, we observed that animals treated with naloxone presented an earlier onset (30 minutes) of the diarrheal effect caused by castor oil and that both ECL and morphine inhibited this outcome. This could indicate that in our experimental conditions, there has been a constitutive activation of opioid receptors in the bowel whose basal activation overlaps the antidiarrheal effects of the castor oil. Alternatively, naloxone might have exerted inverse agonist activity (Sadée et al. 2005), thus promoting the stimulation of neurons in the myenteric plexus (Cruz et al. 1996). This interpretation is corroborated by the fact that the castor oil induced diarrhea was observed after 60 minutes. A parallel can be drawn between the experimental results from the modulation of the opioid system in mice with Complete Freund's Adjuvant (CFA)-induced hyperalgesia, in which model naloxone promotes a short-duration mechanical hyperalgesia (60 minutes) after the cease of the initial hyperalgesia induced by CFA (Corder et al. 2013).

Triterpenes are another class of compounds isolated from parts of Combretum leprosum, among which are the pentacyclic terpenes, namely arjunolic acid, from the root and leaves, $3 \beta, 6 \beta, 16 \beta$ trihydroxy-lup-20(29)-ene, from the roots, leaves and flowers, lupeol from stem bark. It is also composed of cycloartane triterpenes like mollic acid, isolated from the roots, leaves and flowers, $4 \alpha$-carboxy-3 $\beta, 16 \alpha$-dihydroxy-24-cycloartane and $4 \alpha$-carboxy-1 $\alpha, 3 \beta$-dihydroxy-25-trans-23(24)cycloartane, both of the latter isolated from the flowers (Facundo et al. 2008). In a clinical setting, the contribution of the effects of these compounds towards the antidiarrheal effect of the ECL could be hypothesized considering that: (1) Pentacyclic triterpenoids isolated from the stem bark of the Combretaceae Terminalia superba have been shown active against the bacteria Escherichia coli, Salmonella typhi and Shigella flexenari (Tabopda et al. 2009); (2) Escherichia spp., Salmonella spp and
Shigella spp. are examples of the primary causes of traveller's diarrhea (Steffen et al. 2015).

Furthermore, it has been reported that extracts from some African plant species from the Combretaceae family possess antimicrobial activity against pathogens that commonly cause infectious diarrhea (Escherichia coli) with minimal inhibitory concentrations between 0.1 and $6.0 \mathrm{mg} / \mathrm{ml}$ (Eloff et al. 2008). Despite the fact that, to our knowledge, there are no reports that the ECL combats the microorganisms that cause diarrhea; it is plausible that, in a clinical context in which the diarrhea is caused by bacteria, ECL could supposedly exert an antimicrobial activity in a synergistic manner towards the treatment of diarrhea.

This study has added another biologically relevant effect of a stem bark extract of the Combretum leprosum plant. The antidiarrheal activity of this extract was expected, given the classes of compounds that have already been isolated and described as components of Combretum leprosum, but the exact identity of these remains to be further investigated. Moreover, the mechanism through which ECL exerts an antidiarrheal effect seems not to result from antisecretory activity; instead, it appears to be related to inhibitory effects of the propulsive contractions involved in intestinal motility. Further studies are necessary to establish details about which parts of the small and large intestines present alteration in motility due to the extract of Combretum leprosum.

\section{ACKNOWLEDGMENTS}

The author Paulo Marques da Silva Cavalcanti thanks the financial support of the Fundação de Amparo à Pesquisa do Piauí (FAPEPI) and Conselho Nacional de Desenvolvimento Científico e Tecnológico (CNPq). 


\section{REFERENCES}

AGRA MF, SILVA KN, BASÍLIO IJLD, FREITAS PF AND BARBOSA-FILHO JM. 2008. Survey of medicinal plants used in the region Northeast of Brazil. Braz J Pharmacogn 18: 472-508.

ALVES FILHO FC, CAVALCANTI PMS, PASSAGLIA RCAT AND BALLEJO G. 2015. Long-lasting endotheliumdependent relaxation of isolated arteries caused by an extract from the bark of Combretum leprosum. Einstein 13(3): 395-403.

ANIAGU SO, BINDA LG, NWINYI FC, ORISADIPE A, AMOS S, WAMBEBE C AND GAMANIEL K. 2005. Anti-diarrhoeal and ulcer-protective effects of the aqueous root extract of Guiera senegalensis in rodents. J Ethnopharmacol 97: 549-554.

AWOUTERS F, NIEMEGEERS CJ AND JANSSEN PA. 1983. Pharmacology of antidiarrheal drugs. Annu Rev Pharmacol Toxicol 23: 279-301.

AWOUTERS F, NIEMEGEERS CJ, LENAERTS FM AND JANSSEN PA. 1978. Delay of castor oil diarrhoea in rats: a new way to evaluate inhibitors of prostaglandin biosynthesis. J Pharm Pharmacol 30: 41-45.

BEUBLER E AND LEMBECK F. 1980. Inhibition by morphine of prostaglandin $\mathrm{E}_{1}$-stimulated secretion and cyclic adenosine 3',5'-monophosphate formation in the rat jejunum in vivo. Br J Pharmac 68: 513-518.

BUHARALIOĞLU CK AND AKAR F. 2002. The reactivity of serotonin, acetylcholine and kcl-induced contractions to relaxant agents in the rat gastric fundus. Pharmacol Res 45(4): 325-331.

COCK IE. 2015. The medicinal properties and phytochemistry of plants of the genus Terminalia (Combretaceae). Inflammopharmacol 23(5): 203-229.

CORDER G ET AL. 2013. Constitutive $\mu$-opioid receptor activity leads to long-term endogenous analgesia and dependence. Science 341: 1394-1399.

CRUZ SL, VILLARREAL JE AND VOLKOW ND. 1996. Further evidence that naloxone acts as an inverse opiate agonist: implications for drug dependence and withdrawal. Life Sci 58(26): 381-389.

DI CARLO G, AUTORE G, IZZO AA, MAIOLINO P, MASCOLO N, VIOLA P, DIURNO MV AND CAPASSO F. 1993. Inhibition of intestinal motility and secretion by flavonoids in mice and rats: structure-activity relationships. J Pharm Pharmacol 45: 1052-1059.

ELOFF JN, KATERERE DR AND MCGAW LJ. 2008. The biological activity and chemistry of the southern African Combretaceae. J Ethnopharmacol 119: 686-699.

FACUNDO VA, ANDRADE CHS, SILVEIRA ER, BRAZFILHO R AND HUFFORD CD. 1993. Triterpenes and flavonoids from Combretum leprosum. Phytochemistry 32 (2): 411-415.
FACUNDO VA, RIOS KA, MOREIRA LS, MILITÃO JSLT, STABELLI RG, BRAZ-FILHO R AND SILVEIRA ER. 2008. Two new cycloartanes from Combretum leprosum Mart. (Combretaceae). Latinoam Quim 36: 76-82.

FIELD M. 2003. Intestinal ion transport and the pathophysiology of diarrhea. J Clin Invest 111(7): 931943.

GURGEL LA, SILVA RM, SANTOS FA, MARTINS DTO, MATTOS PO AND RAO VSN. 2001. Studies on the Antidiarrhoeal Effect of Dragon's Blood from Croton urucurana. Phytother Res 15: 319-322.

HORINOUCHI CDS, MENDES DAGB, SOLEY BS, PIETROVSKI EF, FACUNDO VA, SANTOS AR, CABRINI DA AND OTUKI MF. 2013. Combretum leprosum Mart. (Combretaceae): potential as an antiproliferative and anti-inflammatory agent. J Ethnopharmacol 145(1): 311-319.

LEFEBVRE RA AND HORACEK J. 1992. Relaxant effects of BRL 38227 and pinacidil on the rat gastric fundus. Eur J Pharmacol 214(1): 1-6.

LIU L ET AL. 2012. Global, regional, and national causes of child mortality: an updated systematic analysis for 2010 with time trends since 2000. Lancet 379(9832): 21512161.

LOPES LS, MARQUES RB, PEREIRA SS, AYRES MCC, CHAVES MH, CAVALHEIRO AJ, VIEIRA JÚNIOR GM AND ALMEIDA FRC. 2010. Antinociceptive effect on mice of the hydroalcoholic fraction and (-) epicatechin obtained from Combretum leprosum Mart \& Eich. Braz J Med Biol Res 43: 1184-1192.

MATOS FJA. 1998. Farmácias Vivas. Fortaleza: EUFC, $3^{\text {a }}$ ed., $219 \mathrm{p}$.

MORAES LS, ROHOR BZ, AREAL LB, PEREIRA EV, SANTOS AM, FACUNDO VA, SANTOS AR, PIRES RG AND MARTINS-SILVA C. 2016. Medicinal plant Combretum leprosum Mart. ameliorates motor, biochemical and molecular alterations in a Parkinson $>\mathrm{s}$ disease model induced by MPTP. J Ethnopharmacol 185: 68-76.

NUNES PHM, CAVALCANTI PMS, GALVÃO SMP AND MARTINS MCC. 2009. Antiulcerogenic activity of Combretum leprosum. Pharmazie 64: 58-62.

OLIVEIRA OW AND PETROVICK PR. 2010. Secagem por aspersão (spray drying) de extratos vegetais: bases e aplicações. Rev Bras Farmacogn 20: 641-650.

PETRI JR WA, MILLER M, BINDER HJ, LEVINE MM, DILLINGHAM R AND GUERRANT RL. 2008. Enteric infections, diarrhea, and their impact on function and development. J Clin Invest 118: 1277-1290.

PIETROVSKI EF, ROSA KA, FACUNDO VA, RIOS K, MARQUES MCA AND SANTOS ARS. 2006. Antinociceptive properties of the ethanolic extract and of the triterpene 3b,6b,16b-trihidroxilup-20(29)-ene obtained 
from the flowers of Combretum leprosum in mice. Pharmacol Biochem Behav 83: 90-99.

POGGIOLI R, BENELLI A, ARLETTI R, CAVAZZUTI E AND BERTOLINI A. 1995. $\mathrm{K}^{\div}$channel openers delay intestinal transit and have antidiarrheal activity. Eur $\mathrm{J}$ Pharmacol 287: 207-209.

ROBERT A, NEZAMIS JE, LANCASTER C, HANCHAR AJ AND KLEPPERN MS. 1976. Enteropooling assay: a test for diarrhea produced by prostaglandins. Prostaglandins 11(5): 809-828.

SADÉE W, WANG D AND BILSKY E. 2005. Basal opioid receptor activity, neutral antagonists, and therapeutic opportunities. Life Sci 76: 1472-1437.

SHENG Z, YAN X, ZHANG R, NI H, CUI Y, GE J AND SHAN A. 2016. Assessment of the antidiarrhoeal properties of the aqueous extract and its soluble fractions of Chebulae Fructus (Terminalia chebula fruits). Pharm Biol 54: 1847-1856.

SILVERSTEIN LJ, SWANSON BG AND MOFFETT D. 1996. Procyanidin from black beans (Phaseolus vulgaris) inhibits nutrient and electrolyte absorption in isolated rat ileum and induces secretion of chloride ion. J Nutr 126 (6): 1688-1695.
SMAILI SS, CAVALCANTI PM, OSHIRO MEM, FERREIRA AT AND JURKIEWICZ A. 1998. $\mathrm{Ca}^{2+}$ release-activated channels in rat stomach smooth muscle cells. Eur J Pharmacol 342: 119-122.

STEFFEN R, HILL DR AND DUPONT HL. 2015. Traveler's diarrhea: A clinical review. JAMA 313(1): 71-80.

TABOPDA TK, NGOUPAYO J, KHAN TANOLI SA, MITAINE-OFFER AC, NGADJUI BT, ALI MS, LUU B AND LACAILLE-DUBOIS MA. 2009. Antimicrobial pentacyclic triterpenoids from Terminalia superba. Planta Med 75(5): 522-527.

VISWANATHAN S, THIRUGNANA SAMBANTHAM P, BAPNA JS AND KAMESWARAN L. 1984. Flavonoidinduced delay in the small intestinal transit: possible mechanism of action. Arch Int Pharmacodyn Ther 270: 151-157.

WALKER CL, RUDAN I, LIU L, NAIR H, THEODORATOU E, BHUTTA ZA, O'BRIEN KL, CAMPBELL H AND BLACK RE. 2013. Global burden of childhood pneumonia and diarrhoea. Lancet. 381(9875): 1405-1416.

WOOD JD. 2010. Enteric nervous system: sensory physiology, diarrhea and constipation. Curr Opin Gastroenterol 26: 102-108. 